\title{
Conflict of Laws in Cross-Strait Air Transport: Issues and Solutions
}

Chaohan Zhang* \& Luping Zhang**

\begin{abstract}
Since the political and legal systems are different between mainland China and Taiwan, conflict of laws issues arose in both public and private air transport laws after the launch of direct routes. Three models can be used as solutions to these issues: uniform substantive law, conflict of laws, and agreements by private institutions. The uniform substantive law model is ideal but not feasible; the conflict of laws model is possible but not realistic. The agreements by private institutions model respects private autonomy, which seems to be a supplementary yet feasible option with fragmented and conservative characteristics. Based on the characteristics of each model, the ideal way to solve this issue is to prioritise the model of agreements by carriers at this early stage and, finally, to consider uniform conflict of laws rules or substantive law when the opportunity is mature or the ultimate reunification is realised.
\end{abstract}

\section{Keywords}

Cross-Strait Direct Flights, Conflict of Laws, Uniform Substantive Law, Interregional Conflict of Laws, Agreement Model

* Associate Professor \& Deputy Director of Bin Cheng Institute of Air and Space Law of China Northwestern University of Political Science and Law; Executive Editor of China Aviation Law Review. LL.M. (NWUPL), Ph.D. (Jilin/Montreal). The author may be contacted at: charley135@163.com /Address: Post Box 89, No.300 South Chang'an Road, Yan Ta District, Xi'an, Shaanxi, China.

** Ph.D. candidate in law at King's College London; Attorney-at-Law (New York Bar); Editor of China Aviation Law Review. LL.B. (Jinan U.), LL.M. (NYU \& Leiden). ORCID: http://orcid.org/0000-0002-9276-4133. The author may be contacted at: luping.zhang@kcl.ac.uk/Address: Flat 23, West Kensington Mansion, W14 9PE, London, United Kingdom. All websites cited in this article were last visited on October 28, 2019. 


\section{Introduction: Background and Question}

To promote cross-strait business and trade and facilitate travel, the chairperson of the Association for Relations across the Taiwan Straits, Chen Yunlin, and the chairperson of the Straits Exchange Foundation, Chiang Pin-kung, signed the CrossStrait Air Transport Agreement (hereinafter the Agreement) ${ }^{1}$ in Taipei on November 4 , 2008, after a period of negotiation on equal terms. The agreement stipulated that the northern route of the direct cross-strait airways would be launched on December 15, 2008, which signified the official launch of the "Three Links." This was especially meaningful for cross-strait travel.

According to the Agreement, both parties agreed to launch the northern twoway direct route of the Taiwan Strait and established a direct transfer procedure of the air control departments of the two sides. Both parties also agreed on continuing negotiations regarding the southern route and other more convenient routes. On April 26, 2009, both parties signed the supplementary agreement, ${ }^{2}$ and on July 29 , 2009 , the launch of the second northern route and the southern route signified the full launch of the direct routes.

Since the launch of the direct cross-strait flights in 2008, the two sides have developed communication, economic and social cooperation for the expansion of routes and carriers, the simplification of administrative approval procedures, and the growth of flights and cargos. Between 61 ports in the mainland and 10 ports in Taiwan, 26 passenger airlines currently operate 817 passenger flights, while 8 cargo airlines operate 77 cargo flights. Annual passenger transportation exceeds 10 million, and annual cargo transportation exceeds 0.4 million tons. ${ }^{3}$ The direct routes have promoted free trade and transfer of personnel, goods, capital, and information to bring economic development and benefit of the people.

When an air accident involves one of the direct flights, there will be issues of compensation for the victims. The political systems and air laws of Taiwan, however,

1 Cross-Strait Air Transport Agreement (Nov.5, 2008) [海峡两岸空运协议], available at http://www.gov.cn/test/200811/05/content_1140329.htm.

2 Association for Relations across the Taiwan Straits and Straits Exchange Foundation signed the Cross-Strait Supplementary Air Transport Agreement (Apr. 26, 2009) [海峡两岸空运补充协议], available at http://www.gov.cn/ jrzg/2009-04/26/content_1296611.htm.

3 Civil Aviation Administration, The 40th Anniversary of the Publication of the Message to Compatriots in Taiwan Civil Aviation Has Played an Important Role in Great Communication, Great Relationship, and Great Cooperation (Jan. 2, 2019) [《告台湾同胞书》发表40周年 民航在两岸大交流大交往大合作中发挥积极作用], available at http:// www.caac.gov.cn/XWZX/MHYW/201901/t20190104_193845.html. 
diverge from those of mainland China. A different application of different laws will influence the protection of the victims' rights and the development of business and trade. Therefore, in reviewing conflict of laws issues in cross-strait air transport, discussion, research coordination methods and solution models to conflict of laws issues will pose an unavoidable practical challenge.

\section{Characterisation and Influence of Conflict of Laws Issues in Cross-Strait Air Transport}

"Conflict of laws" refers to a conflicting status in the application of laws where different laws of different countries or regions have exerted jurisdiction on the same foreign-related civil legal relationship. ${ }^{4}$ Conflict of laws in cross-strait air transport means which law will apply when there is an air transport conflict: should Taiwanese 'law,' mainland law, or laws of other regions apply? When an air accident occurs, whether conflict of laws will constitute an interregional conflict of laws or an international conflict of laws depends on the categorisation of cross-strait air transport, or whether it is considered cabotage or international air transport. This will determine the jurisdiction and laws applicable to a particular case. Therefore, it is important to determine the legal nature of cross-strait air transport.

\section{A. Cabotage versus International Air Transport: Determination of the Nature of the Legal Conflict in Cross-Strait Air Transport}

Regarding the nature of cross-strait air transportation, current theories may interpret it as international air transport, cabotage, special cabotage, quasi-international air transport, or cross-strait air transport. ${ }^{5}$

Taiwan regards cross-strait air routes (including Hong Kong and Macau) as "neither cabotage nor international air transport." In 1995, the Ministry of Transportation of Taiwan issued the Measures of the Establishment of Offshore Shipping Centres, ${ }^{6}$ in which Article 3 defines the cross-strait shipping route as a "special shipping route" between cabotage and an international route.

4 D. Han \& Y. Xiao (eds.), International Private Law [国际私法] 83 (3d. ed. 2014).

5 X. Hao, A Comparative Study on Air Laws Between Both Sides of Taiwan Straits [海峡两岸航空法之比较研究] 313 (2013).

6 The Ministry of Communications (1995) issued the order No. 84172 on May 5, 1995, and revised it six times in 1997, 1998,2004 and 2010. 
Mainland China insisted on the theory of 'cabotage' initially. However, under the conclusion of the "One China with Respective Interpretations" principle, which resulted from the Wang-Koo Talks, mainland China made great compromises under the principle of 'One China.' In cross-strait transportation, the mainland has implemented the policy and principle of "air after sea, people after cargos." In 1996, under Article 3 of the Management Measures of Cross-Taiwan Straits Shipping ${ }^{7}$ and Article 3 (2) of the Notice on Certain Issues of the Implementation of the Management Measures of Cross-Taiwan Straits Shipping ${ }^{8}$ issued by the Ministry of Transportation, cross-strait shipping was defined as "special domestic transport." Therefore, some scholars maintain that there is an analogy between shipping and air transport and that the latter can also be categorised naturally as "special cabotage."

As to the nature of the cross-strait air routes, mainland China will never regard them as 'international' under the "One China" principle. Furthermore, they do not fit the definition of "international air transport"10 under the Convention for the Unification of Certain Rules relating to International Carriage by Air (1929), known as the Warsaw Convention or the Convention for the Unification of Certain Rules for International Carriage by Air (1999), known as the Montreal Convention which stipulates that either the place of departure, destination, or stop must not be a member state. ${ }^{11}$ Since mainland China and Taiwan belong to the same sovereignty, it is not correct to categorise the cross-strait air routes as international air transport.

7 Article 3 of Management Measures of Cross-Taiwan Straits Shipping stipulates that "the cross-strait air transportation belongs to a special management of domestic transportation," available at http:/www.people.com.cn/zixun/flfgk/item/ dwjjf/falv/8/8-1-30.html.

8 Article 3 (3) of the Notice on Certain Issues of the Implementation of the Management Measures of Cross-Taiwan Straits Shipping stipulates that "the cross-strait air transportation belongs to special management of cabotage, and shall be managed by foreign trading transportation, of which cargo transportation agreement will apply Chapter 4 of the PRC Law of the Sea...," available at http://www.npc.gov.cn/wxzl/wxzl/2000-12/05/content_4575.htm.

9 Hao, supra note 5, at 313.

10 Article 1 of the Warsaw Convention and Article 1 of the Montreal Convention have the same criteria for international transport. The expression "international carriage" means any carriage in which, according to the agreement between the parties, the place of departure and the place of destination, whether or not there is a break in the carriage or a transhipment, are situated either within the territories of two States Parties, or within the territory of a single State Party if there is an agreed stopping place within the territory of another State, even if that State is not a State Party. Carriage between two points within the territory of a single State Party without an agreed stopping place within the territory of another State is not international carriage for the purposes of the Montreal Convention. Simply put, the standard of "international carriage" does not depend on whether the airline that operates the transport or the State in which aircraft belongs is the party of the Convention, and regardless of the nationality of the passenger or cargo contained therein, these factors are not related to "international transport." The criteria for determining the "international nature" of the shipment depend entirely on whether the origin of the transport, whether the destination is in the territory of the States Party, or whether the two are within the territory of a single State Party and have an "agreed stopping place" within the territory of another State, even if that State is not a State Party.

11 Warsaw Convention art. 1(2); Montreal Convention art 1(2). 
However, under the basic nature of cabotage, should the routes be categorised as "traditional cabotage or special cabotage"? Is it necessary to make such a distinction? Some mainland scholars think it is important to be aware that the two lands belong to different customs territories and that the cross-strait air routes are distinctive and should be categorised as "special cabotage.", Taiwanese scholars, meanwhile, have proposed "international air transport," "quasi-international air transport," and "cross-strait air transport," which cannot represent the nature of the cross-strait air routes. ${ }^{13}$ It is advisable to learn from the experiences of other countries, such as the two Germanys before reunification and the two Koreas, which may be helpful for a comparative study, especially if Germany after reunification were used as a successful example. ${ }^{14}$

As to whether the cross-strait air routes are "cabotage or special cabotage," the authors think that after excluding international routes or international air transport, there is no need to dwell on the distinction between traditional and special, because such a distinction will not be beneficial to the passengers' rights. As to the air transport between the mainland and Taiwan, especially the cross-strait direct routes, it pertains to a domestic (interregional) law domain, where international law is not applicable. Meanwhile, Taiwan is excluded from the Warsaw System ${ }^{15}$ and the Montreal Convention ${ }^{16}$ based on the "One China" principle. In addition, mainland China and Taiwan belong to different social and legal systems, as well as different jurisdictions. Relevant laws and regulations have both common ground, or similarities, and differences. Therefore, the legal issue (mostly private law) on the cross-strait direct routes concerns, in essence, interregional conflict of laws rules regarding issues reflected in air transportation.

12 Hao, supra note 5, at 313.

13 Sheng-ti Gau, Governmental Representation for Territories in the International Civil Aviation Organization: A Case Study (unpublished PhD. Dissertation, Leiden University, 1997).

14 Zhixiang Lin, Study on the Related Legal Issues of Direct Shipping Terms across the Taiwan Straits (2008) (unpublished LL.M. Thesis, National Taiwan Ocean University), at 45.

15 The Warsaw System contains eight legal documents centered by the Warsaw Convention: 1929 Convention on the Unification of Certain Rules of International Air Transport; 1955 Hague Protocol to Amend the Convention for the Unification of Certain Rules Relating to International Carriage by Air; 1961 Guadalajara Convention supplementary to the Warsaw Convention for the unification of certain rules relating to international carriage by air performed by a person other than the contracting carrier; 1971 Protocol to amend the convention for the unification of certain rules relating to international carriage by air; Four 1975 Montreal Protocol amending the Warsaw Convention.

16 The Montreal Convention took effect on November 4, 2003. As the 94th Contracting State, China ratified it on July 31, 2005. Up until January 18, 2019, this Convention had 135 sovereign states and 1 regional organization-the European Union, available at https://www.icao.int/secretariat/legal/List\%20of\%20Parties/Mt199_EN.pdf. 


\section{B. The Impact of the Nature of the Cross-Strait Legal Conflict}

When the nature of the cross-strait air routes is determined separately, the jurisdiction and application of laws are different. The result will influence not only passengers' rights but also cross-strait political relationships.

The liability limitation under the mainland's Civil Aviation Law, enacted in 1995, distinguishes international air transport from cabotage, with different applicable limitations. ${ }^{17}$ If the cross-strait air transport is deemed international air transport, only rules of jurisdiction and liability under international conventions can be applied where the mainland is a party. These standards under international conventions are different from domestic rules. Therefore, it is crucial to divide a dispute into international and domestic. This distinction influences not only the carriers' liability but also its limitation. ${ }^{18}$ In comparison, Taiwan regards international air transport and cabotage as the same in terms of air carriers' liability. Therefore, the determination of the nature of cross-strait air transport has a strong influence on the jurisdiction, on the application of laws, and, further, on passengers' rights.

From the arguments, the nature of the legal conflict in cross-strait air transportation is clearly 'interregional.' This kind of legal conflict is under different jurisdictions and legal systems.

\section{Reasons for and Effects of the Legal Conflict in Cross-Strait Air Transport}

\section{A. Reasons for the Legal Conflict in Cross-Strait Air Transport}

Interregional legal conflict is not prevalent in every country. There should be generally four conditions: (1) there are different legal systems in the jurisdiction of one country; (2) communication between different jurisdictions will lead to many interregional legal relationships; (3) different legal jurisdictions acknowledge the legal status of each other's citizens in their own legal jurisdictions; and (4) different legal jurisdictions acknowledge the extra-territorial legal effects under certain conditions. ${ }^{19}$

First, the mainland and Taiwan have long been separated and even in tension.

\footnotetext{
17 PRC Civil Aviation Law [中华人民共和国民用航空法], arts. 128 \& 129.

18 Lin, supra note 14 , at 139.

19 Jin Huang, Research on International Legal Issues IN China [中国的区际法律问题研究] 7 (2001).
} 
Therefore, both have formed different political, social, economic, and legal system for historical reasons. Each has a complete legal system and independent legislatures, judicial, and executive powers. Even in air law, there has long been a pronounced difference in air (legal) terms, as can be seen in the following examples: "tongyong hangkong ye [通用航空业]-putong hangkong ye [普通航空业] (general aviation business)”; “jichang/konggang [机场/空港]-hangkong zhan [航空站] (airport terminal)"; “jichang quyu [机场区域]-feixing chang [飞行场] (airfield)”; “feixing [飞 行]-feihang [飞航] (flight)"; "hangban feixing [航班飞行]-dingqi feihang [定期飞航] (scheduled flights)"; “kongzhong jiaotong guanli [空中交通管理] (air traffic control)feixing guanzhi [飞行管制] (flight control)”; “kongzhong jinqu [空中禁区]-jinhang qu [禁航区] (prohibited area)”; “gaojing fuwu [告警服务]-shouzhu yewu [守助业务] (alerting service)."20

Second, since December 15, 2008, the two sides have accomplished direct transportation in terms of the sea, air, and mail. The mainland and Taiwan have maintained soothed tension in recent years. Cross-strait air transport has been developing rapidly in accordance with the two sides' efforts. In the first halves of 2010, 2011, and 2012, the cross-strait air routes accommodated 5.83 million, 7.16 million, and 4.40 million passengers, respectively, showing annual growth of 87.6 percent, 22.9 percent, and 20 percent, respectively. To date, the two sides have established a total of 71 passenger and cargo terminals, with an average load factor of over 80 percent. $^{21}$ Such rapid development in cross-strait air transport will engender many legal conflicts in private and public air law.

Third, with direct cross-strait flights, the subjects served by air transport in the mainland and Taiwan have won each other's acknowledgements of legal status in the respective jurisdictions. From the mapping of the two sides' air transport, it can be seen that both sides: (1) enforce strict market access mechanisms; (2) follow the agreement certifying that 'both parties agree that airlines registered in both sides with capitals from both sides operate passenger and cargo flights with permission, ${ }^{22}$ and (3) strictly control the number of operating airlines for each route. According to certain regulations issued by the civil aviation authorities of both sides, the mainland and Taiwan have acknowledged a certain legal status of subjects served by air transport in each other's jurisdictions. For example, Taiwan's Ministry of Transport has issued

20 For details on differences in aviation legal terms between the two sides of Cross-Strait, see Hao, supra note 5, at 413.

21 X. Zeng \& F. Zhu, Air Transportation Industry: Current Status and Feature Prospects of Cross-Strait Aviation Development [航空运输行业: 两岸航空发展现状与未来展望], available at https://finance.qq.com/a/20120919/003148. htm. See also supra note 3 .

22 Cross-strait Air Transport Agreement, art. 2. 
and implemented the following: Measures of Licensing of Indirect Transport of Civil Aviation between Taiwan and the Mainland, ${ }^{23}$ Procedure for Application of Flying over Mainland Airspace of Flag Carriers, ${ }^{24}$ and Procedure for Application for the Cross-Strait Spring Festival Charter of Mainland Airlines. ${ }^{25}$ Mainland Civil Aviation Administration ("CAA"), meanwhile, has issued and implemented Licensing of Operation of Air Routes of Foreign Airlines (CCAR-287), ${ }^{26}$ Implementation Rules of Non-Scheduled Air Routes of Foreign Air Transportation Enterprises (CCAR-119TRR1), ${ }^{27}$ and Rules on Foreign Investment in Civil Aviation (CCAR-201LR). ${ }^{28}$ Article 2 of the Rules of Applicable Laws on Judging Taiwan-related Civil and Commercial Cases, by the Supreme People's Court (Legal Implementation [2010]19), entered into force on January 1, 2011, stipulates that: "Taiwanese parties will participate in the civil litigation with equal rights and obligation as mainland parties, of which legal rights will be equally protected by law." ${ }^{29}$

Fourth, the two sides have acknowledged the extra-territorial legal effects of each other's laws. For example, on April 9, 1991, former president of the Supreme People's Court Ren Jiaxin solemnly declared in the Working Report of the Supreme People's Court, passed by the Fourth Session of the Seventh National People's Congress, that:

The civil behaviours of Taiwanese residents in Taiwan and civil rights obtained by Taiwanese laws and regulations will be acknowledged if they do not violate the basic principles of the People's Republic of China and social public interests. As to the civil rulings by the Taiwan courts, [they] will follow the same principle and

23 The Measures were launched by No. 8414 Order by the Ministry of Transportation on May 1, 1995; re-launched by No. 8641 Order by the Ministry of Transportation on June 1, 1997; amended and launched by No. 091B000112 Order by the Ministry of Transportation on September 24, 2002; amended and launched by No. 093B000017 Order on February $28,2004$.

24 This procedure was launched by Letter No. 094009134 by the Ministry of Transportation on August 15, 2005.

25 This procedure was launched by Letter No. 0940014122 by the Ministry of Transportation on December 1, 2005.

26 CCAR-287 art. 35. It provides: "The application for business license by air transport enterprises of the Hong Kong Special Administrative Region, the Macao Special Administrative Region and the Taiwan region of the People's Republic of China shall be implemented in accordance with these Provisions."

27 CCAR-119TR-R1 art. 30. It provides: "Aircraft owners or operators of the Hong Kong Special Administrative Region and the Macao Special Administrative Region applying for non-scheduled flight operations permits between the Hong Kong Special Administrative Region and the Macao Special Administrative Region and the mainland of the People's Republic of China, aircraft owners or operators in Taiwan applying for non-scheduled flight operations between Taiwan and the People's Republic of China, shall be made with reference to these Regulations."

28 CCAR-201LR art. 16. It provides: "Companies, enterprises, other economic organization or individual for Hong Kong, Macao Special Administrative Region and Taiwan region investing in the civil aviation industry in other provinces, autonomous regions and municipalities directly under the Central Government, shall be made with reference to these regulations."

29 Provisions of the Supreme People's Court on the Application of Law in the Trial of Taiwan-Related Civil and Commercial Cases [最高人民法院关于审理涉台民商事案件法律适用问题的规定], art. 2. 
deal with the issue of legal effect based on different situations. ${ }^{30}$

In 1998, the Supreme People's Court issued the Supplementary Rules on the Acknowledgement of Certain Civil Rulings in the Taiwan Region by the People's Court. This clearly demonstrates that the mainland conditionally acknowledges certain Taiwanese civil rulings by judicial interpretations. In addition, it has indirectly acknowledged that Taiwanese civil and commercial 'law' has the same legal effect under certain conditions and to a certain extent. The 1992 Regulation on the People's Relationship between Taiwan and Mainland ${ }^{31}$ (hereinafter People's Relationship Regulation) indirectly acknowledged the legal effect of mainland laws on marriage, adoption, property rights, and obligations.

\section{B. Certain Legal Conflicts in Cross-Strait Air Transport}

Certain legal conflicts in cross-strait air transport will, on the one hand, reflect on technical regulations, such as airlines operating cross-strait air routes; air routes, flights, fares, cargo fees, tax donation, and tax reduction and exemption; air route planning and ground crew, aviation facilities, air traffic control, and provision of intelligence; and custom, quarantine, applicable laws for taxation, settlement of disputes, aviation incidents, and search and rescue. ${ }^{32}$ On the other hand, there are many legal conflicts in public air law and private air law. For example, in the field of public law, there are conflicts regarding the legal nature of the cross-strait air routes, air traffic, freedoms of air, aircraft registration and symbols, circumscription and linkage of Flight Information Region ("FIR") and Air Defence Identification Zone (“ADIZ"), prohibition on crimes against aircrafts, rights over aircrafts and certificates of airworthiness, IDs of aircrew, and operation and supervision of aviation. ${ }^{33}$ In the private law field, meanwhile, conflicts focus on the responsibility and compensation in air transportation, the way to choose applicable law, courts, litigation procedure, and statutes of limitation, and the coordination to address legal conflicts on liability limitation on compensation and enforcement when there is an air accident, delay, or

30 Report on the Work of the Supreme People's Court (1991) [1991年最高人民法院工作报告], available at http://www. gov.cn/test/2008-03/27/content_929896.htm.

31 Act Governing Relations between the People of the Taiwan Area and the Mainland Area [台湾地区与大陆地区人民 关系条例] was published by No. 3736 President Order and amended 11 times in 1993, 1994, 1995, 1996, 1997, 2000, 2002, 2003 and 2006.

32 Guanghua Chen, Research on Supporting Measures for Cross-Strait General Aviation, Report of National Policy Research Foundation, July 16, 2002.

33 Hao, supra note 5, at 316. 
other conflicts of interest between the carrier and victims. ${ }^{34}$

Among many legal conflicts regarding the cross-strait direct flights, this article will focus on typical examples in the field of private law. The essence of private law issues of the cross-strait direct air routes is a reflection of the two sides' legal conflicts in the field of air transport. Since the mainland and Taiwan maintain different social mechanisms and different legal system and jurisdictions, the cross-strait direct flights covering two sides and even multiple regions (e.g., Hong Kong and Macau) will inevitably engender many legal conflicts as follows.

\section{Legal Conflict of Compensation Based on Substantive Rules}

Legal conflicts in cross-strait air transport are mostly based on the substantive rules on compensation. For example, the two sides have multiple conflicts on passenger transportation, cargo, baggage delivery and legal rules, principles of liability, subjects of liability, duration, limitation, exemption clauses, insurance, and statutes of limitation. Annex 1 presents the comparison. ${ }^{35}$

\section{Conflict of Jurisdiction in Compensation Lawsuits}

The two sides have a clear difference in the jurisdiction in compensation lawsuits. Article 27 of the Civil Procedure Law of the People's Republic of China, as amended in 2012, stipulates that: "The jurisdiction of air transportation and combined transportation contracted will belong to courts of departure, destination, or place of residence of the defendant(s)." Article 29 stipulates that: "The lawsuits due to aviation accidents will belong to the jurisdiction of the place of accident, the first landing of aircraft, or the place of residence of the defendant(s)." If it is an international air transport liability lawsuit, the jurisdictional rules will follow Article 33 of the Montreal Convention. ${ }^{36}$

Meanwhile, Taiwan's Civil Aviation Law stipulates different jurisdictions based on different natures of the lawsuits. Article 15 stipulates that: "Lawsuits asking for compensation based on the crash of aircraft or aviation accidents will belong to the

34 Hongji Yang, Applicable Laws and Conflict of Laws Issues in Air Transportation in the Cross-Strait Three Districts [两岸三区空运之法律适用及冲突问题], in Collection of Essays In Cross-Strait Civil Aviation [海峡两岸民航运输 应用论文集] (Chia-Jui Cheng ed., 1995).

35 See the list of comparison of liability of cross-strait passenger air transportation. See also Hao, supra note 5, at 77-8.

36 Montreal Convention art. 33. It provides: "An action for damages must be brought, at the option of the plaintiff, in the territory of one of the States Parties, either before the court of the domicile of the carrier or of its principal place of business, or where it has a place of business through which contract has been made or before the court at the place of destination, or in the territory of a State Party in which at the time of the accident the passenger has his or her principal and permanent residence (The fifth jurisdictional court)." 
jurisdiction of the place of the first landing, or the place of detained aircraft." Article 97 stipulates:

Lawsuits asking for compensation based on injuries or death out of aircraft crash or other loss of property will belong to the jurisdiction of place of injury; lawsuits asking for compensation based on accidental injuries and death due to embarkation and disembarkation or delayed transportation will belong to the jurisdictions of place of signing the contract or place of destination.

In addition, except if Article 99 applies to the above situations, rules of "Civil Law" and "Civil Procedure Law" will apply. Mainland Civil Aviation Law does not have special regulations on the jurisdiction of aviation compensation lawsuits. As a result, Taiwan is more comprehensive and richer than the mainland in the area of legislation.

\section{Conflict of Interregional Conflict of Laws}

As mentioned before, the cross-strait aviation legal conflict is, in essence, a type of interregional legal conflict. Currently, Taiwan has a clear reference to the interregional private law, ${ }^{37}$ while the mainland does not. ${ }^{38}$ The cross-strait aviation legal conflict leads to the uncertainty of protection of passenger rights in the direct flights. There are many differences in the laws applicable to the cross-strait direct flights, such as applicable laws of transportation contracts, applicable laws of aircraft rights, and applicable laws of passengers' legal capacity and capability, as well as aviation tort law. There are certain differences in the connecting points of conflict of laws rules, choice of law, and balance of values. In the following part, tort law is taken as an example.

In cross-strait air transport, if the dispute is due to a general transportation contract that causes passenger and baggage damage due to aviation accidents, it will be governed by the rules of breach of contract. The passengers would, however, have

37 It is mainly the Regulations on Taiwanese and Mainland's People's Relationship enacted in Taiwan in 1992. The Regulations have many interregional conflicts regarding the provisions such as Articles 41, 43, 44, 47-54, etc.

38 In the absence of interregional codes in the mainland, when Mainland court hears Cross-Strait direct air transport disputes, there are two options: adopting unilateral conflict model or a private law model. As the model of unilateral conflict model mostly applies the law of court, it is sometimes not conducive to the development of the political and cultural missions carried by the direct cross-strait flight. In contrast to the model of international private law, there is dilemma of ignoring the laws and characteristics of interregional private law. It sometimes leads to judicial arbitrariness and it is difficult to play the role of litigation. See Zhili Wang, A Comparative Study on Private Interregional Air Law between the Strait [两岸航空区际法律适用制度比较论纲], 17(5) J. BEIJNG INST. TECH. (Social Sciences Edition) [北京 理工大学学报 (社会科学版)] 118 (2015). 
the right to bring a tort lawsuit. Taiwan's legislation does not have the rules on this issue. Generally, there will not be any positive conflict on the nature of lawsuits.

As for the damage caused by the aircraft to the ground (water) third party, according to Article 161 of the mainland's Civil Aviation Law, the operator of the aircraft will bear the responsibility of default fault. ${ }^{39}$ Article 89 of the Taiwan's Civil Aviation Law, however, imposes strict responsibilities which are presumed regardless of the intent, including either an intentional/negligent act of the aircraft owner, or force majeure. Besides the differences in responsibilities, there are differences in the subjects of responsibility. The mainland's regulations refer to the operator of the aircraft, while Taiwan's one mentions the owner of the aircraft. Therefore, when there is an accident involving a cross-strait direct flight, huge difference lies in the determination of whether to apply mainland laws or Taiwanese laws.

As far as the detailed conflict of laws is concerned, Article 189 of the mainland Civil Aviation Law provides: "The compensation for damages of civil aircraft to the third person on the ground will apply the law of tort. When the civil aircraft damages the third person on public water, the law of the court will apply." In both theory and practice, the mainland often distinguishes the place of the act of tort from that of the result of tort. Article 50 of the 1992 Taiwan "Regulation on People's Relationship" lays down that tort will apply the law of damages, not the law of the act.

Based on the comparison above, both legislatures would take the law of the tort act as the applicable law of aircraft tort act. The mainland legislature, however, follows a flexible choice of conflict of laws pattern, while the court may choose the law between the place of the act of tort and the result of the tort. Meanwhile, the Taiwanese 'legislature' is comparatively specific, so that the court would only apply the law of the result of tort, that is, the law of where the damages are done.

\section{Reflection on Models of Solutions to the Legal Conflict in Cross-Strait Air Transport}

Given the above analysis of the legal conflict of the cross-strait direct air routes,

39 Civil Aviation Law of the People's Republic of China, art. 161. It provides: "Any person who would otherwise be liable under the provisions of this Chapter shall be exonerated from the liability for damage if he proves that the damage was caused solely by the fault of the person who suffers the damage or of the latter's servants or agents. If the person liable proves that the damage was contributed to by the fault of the person who suffers the damage, or of his servants or agents, the compensation shall be reduced to the extent to which such fault contributed to the damage proves that his servant or agent was acting outside the scope of his authority. Where an action is brought by one person to recover the damage arising from the death or injury of another person, and the damage was caused by the fault of such other person, or of his servants or agents, the provisions of the preceding paragraph shall apply." 
there are different levels of substantive laws, procedural laws, and conflict of laws rules in adjusting the cross-strait air transport. As the mainland has been largely influenced by international conventions, ${ }^{40}$ some private law articles directly adopt the context of these conventions. ${ }^{41}$ Taiwanese air law, however, is not bound by international conventions. However, international conventions can be a legal ground for contracts as a part of personal autonomy. In addition, the Taiwanese regulations are comparatively lax without clear rules for legal issues, which leads to inevitably conflicts in private air law. Currently, there is an interregional code for the cross-strait conflict of laws. The mainland Supreme People's Court has issued the Regulation on Applicable Laws on Ruling Taiwan-Related Civil and Commercial Cases, ${ }^{42}$ which ultimately refers to the international conflict of laws rules, with a certain scope. For example, the rule on using nationality as the connecting point in the international privet law cannot be applied. In the specific area of aviation, applying the registered state of the aircraft as the connecting point may not be applied, either. Therefore, resolving the issue of conflict of laws is crucial to the sustainable development of cross-strait air transport.

To date, domestic scholars have discussed three potential models: uniform substantive law, conflict of laws, and agreements by private institutions.

\section{A. Uniform Substantive Law Model: Ideal but Not Feasible}

Uniform substantive law concerns making uniform civil and commercial substantive laws applicable to different jurisdictions. It would adjust cross-interregional civil and commercial legal relationships so that the choice of different jurisdictions and interregional conflict of laws issues will be avoided. Under the "One China" principle, uniform private air law in mainland China and Taiwan and its application directly to the cross-strait air transport relationship, will be a fundamental to resolving the legal conflict by both avoiding conflict between different legal jurisdictions, and ultimately preventing the cross-strait legal conflict. Ziqin Zhu has pointed out that: "If there is an issue of carrier liability and compensation in the cross-strait direct flight, the best way to resolve is to make uniform substantive law to regulate liability and compensation

40 It mainly refers to the 1929 Warsaw Convention and the 1999 Warsaw Convention.

41 Articles 114, 117 and 121 of the Chinese Civil Aviation Law have copied from Articles 6, 9, 14 of the 1929 Warsaw Convention.

42 Provisions of the Supreme People's Court on the Application of Law in the Trial of Taiwan-Related Civil and Commercial Cases [关于审理涉台民商事案件法律适用问题的规定], the 1486th collegial meeting by the Supreme People's Court Judicial Committee on April 26, 2010, available at $\mathrm{http} / / \mathrm{rmfyb}$.chinacourt.org/paper/htm1/2010-12/30/ content_20817.htm. 
after negotiation." 43 Another scholar optimistically thinks that uniform private laws under the framework of "One Country, Two Systems" fits the requirement of uniformity of parts of private laws to satisfy the market economy which is not only necessary, but also feasible. ${ }^{44}$

A uniform substantive law model is both ideal and necessary. Also, it could resolve this issue permanently. This violates, however, the spirit of two basic laws. ${ }^{45}$ According to the rules of these laws, Hong Kong and Macau will maintain the original free enterprise market and lifestyle for 50 years from the beginning of 1997 and 1999, respectively. Therefore, at least in the next 30 years, unless Hong Kong and Macau will relinquish their local air laws and execute a uniform air law with the mainland, unifying the private law of the mainland with that of Hong Kong and Macau is legally groundless. ${ }^{46}$ In this analogy, as far as cross-strait relations are concerned, the two sides will neither fully establish a reunited negotiation mechanism, nor reach an ideal uniform private air law in a short timeframe. Therefore, adopting a uniform substantive law model is very difficult. It would be ideal, but not feasible.

\section{B. Interregional Conflict of Laws Model: Possible but Not Realistic}

When the uniform substantive law path is impracticable, the traditional way to resolve this issue is to follow the conflict of laws model. ${ }^{47}$ It is an indirect model to resolve legal conflicts. The most basic way is to make a conflict of laws code; refer the application of law to a specific substantive law in a specialised area; follow the law to resolve the conflict; and prevent the courts from the dilemma of choosing different substantive laws.

The conflict of laws model relies on two laws: one is the interregional conflict of laws; the other is the specific substantive law selected. Currently, the mainland lacks

43 Ziqin Zhu, Thoughts on Several Legal Issues Facing the Direct Cross-Strait Air Transport [两岸直航面临的若干法律 问题思考], ChINA LeGAL DaILY [法制日报], Dec.7, 2008 (11th ed.).

44 Jingwei Liu, Under the Principle of 'One Country, Two Systems,' The Unification of Private Law in the 'Four Places of the Two Lands' [“一国两制” 原则下, “两岸四地” 的私法统一问题], 18(1) J. CoMP. L. [比较法研究] 17 (2010).

45 These two basic laws are Hong Kong SAR Basic Law [中华人民共和国香港特别行政区基本法] (Passed at the Third Meeting of the Seventh National People's Congress of People's Republic of China on April 4, 1990, enforced from July 1, 1997) and Macau SAR Basic Law [中华人民共和国澳门特别行政区基本法] (Passed at the First Meeting of the Eighth National People's Congress of People's Republic of China on March 31, 1993, enforced from December 20, 1999).

46 Lizhi Wang \& Hui Yang \& J. Nie, The Conflict and Establishment of Private Legae Regime for Cross-Strait Air TRANSPORTATION [两岸航空直航私法冲突与制度构建] 90 (2016).

47 Uniform substantive law and conflicts of law are two basic legal norms that resolve international legal conflicts (including regional legal conflicts) through direct and indirect methods. See Han \& Xiao, supra note 4, at 4-5. 
interregional conflict of laws rules on cross-strait relations. Actually, the current laws adjusting interregional conflict of laws are not sufficient. Chapter 14 of the Civil Aviation Law-The Applicable Laws in the Foreign-related Relationship, does not specify if the term 'foreign' includes "Taiwan-related." The main body of laws applicable to adjusting the cross-strait conflict of laws is departmental rules and local regulations, such as the 1991 Management Measure on Chinese Citizens Traveling from and to Taiwan by the State Council ${ }^{48}$ and the 1988 Meeting Record on Criminal Appeal and Civil Cases related to Taiwan by the Supreme People's Court. ${ }^{49}$ In particular, the 1998 Supreme People's Court's Rules on Recognising Certain Civil Rulings in the Taiwan Region ${ }^{50}$ has clear regulations on recognition principles and procedures of Taiwan civil cases and arbitral awards to facilitate judicial assistance and conflict of laws rules. In addition, on a substantive law level, although the Civil Aviation Law can be easily applied as the basic mechanism to the cross-strait direct flight, there is no operation system of the cross-strait direct flight at this time. It is indeed without practical support. The liability mechanism of this law is designed based on the same legal jurisdiction, but it does not consider the issue of cross-strait air transport besides cabotage and international air transport. Therefore, in the course of applying the said law, there would be some jurisprudential obstacles.

The conflict of laws method can be divided into two categories: one is to comparably apply the international private law method, while the other is to make interregional conflict of laws rules to resolve such issues. Both methods prove to be inadequate, however.

First, to apply the international private law method comparably may exert the same effect as interregional conflict of laws rules. These two methods, however, have obvious constitutional differences. The basis for resolving interregional conflict of laws issues is the constitution. However, resolving international legal conflicts is based not on different constitutions but on actual need based on sovereignty and international communication, such as vested rights and international comity. When comparably applying international private law to resolve interregional conflict of laws issues, the connecting point will be the party's or aircraft's nationality, which

48 Issued by the State Council Order 93 of People's Republic of China on December 17, 1991, amended by the Decision of the State Council on Amending the Measures for the Administration of Chinese Citizens Travelling to or from Taiwan Region on June 14, 2015, available at http://www.gov.cn/zhengce/content/2015-06/18/content_9862.htm.

49 The Supreme People's Court has issued the announcement of Handling Taiwan-related Criminal Complaint Seminar on Civil Cases [最高人民法院印发《处理涉台刑事申诉民事案件座谈会纪要》的通知], available at http://www.scxsls. com/a/20110701/13210.html.

50 Passed at the 957th Meeting of the Supreme People's Court's Trial Committee on January 15, 1998. See Legal Interpretation [1998] 11, available at http:/www.court.gov.cn/shenpan-xiangqing-113.html. 
will not help to resolve the issue of conflict of laws. ${ }^{51}$

Second, since Hong Kong and Macau were repatriated to China, the relationship between Taiwan and the mainland has been less tense. Since the establishment of "Three Links," the mainland's legal conflicts cases related to Hong Kong, Macau, and Taiwan have grown proportionately. In particular, the advent of the cross-strait direct flight has engendered more legal conflicts in maritime and air law. Comparing international private law code will not resolve the issue of conflict of laws in four jurisdictions. Therefore, it is necessary to formulate interregional private law first. Interregional conflict of laws can be divided into two models: one entails developing nationwide uniform interregional conflict of laws rules; the other involves devising interregional conflict of laws rules separately. For these two models, some scholars would maintain: "The former one is a better choice: it can lead to the same results for the same cases to avoid 'forum shopping' and also avoid conflicts of conflict of laws per se, as well as remission, and simplify the issue of characterisation, which will lay a solid foundation of unifying substantive rules cross-strait. ${ }^{, 52}$ The authors, however, think that this model is possible but less meaningful in practice. Since Taiwan is an integral part of China but not fully reunited yet, making nationwide uniform conflict of laws rules would encounter many difficulties and cannot be achieved in a short timeframe. Considering different legal mechanisms and legal concepts, therefore, the most realistic and possible approach after selection will be to formulate interregional conflict of laws rules separately. Some scholars think that, although this is not an optimal alternative, it is still a best option. ${ }^{53}$ Others provide that this currently represents a feasible legislative approach. ${ }^{54}$ For example, Chapter 3 (Civil Relationship) of the People's Relationship Regulation has many rules on interregional

51 See Wang, supra note 38, at 113.

52 D. Han \& J. Huang, Formulating the Interregional Conflict Law to solve the interregional conflict of laws between China's Mainland and Taiwan, Hong Kong and Macao: "Model Regulations on civil law application in mainland China and Taiwan, Hong Kong and Macao” [ 制定区际冲突法以解决我国大陆与台湾、香港、澳门的区际法律冲突《大陆地区与台湾、香港、澳门地区民事法律适用示范条例》], 14(4) J. WuHAN U. (Social Science Edition) [武汉大学 学报 (社会科学版) 55 (1993).

53 Professor Lizhi Wang of the Civil Aviation University of China advocates that, at present, mainland China may temporarily establish a cross-strait aviation interregional private law and name it "Regulations on the Application of Private Law on Cross-Strait Air Transport" (In the design of the system, the application of international aviation conventions, international aviation customs and practices, the determination of national laws, the preservation of public order, the evasion of laws, the remission and transmission, the proof of Taiwan's aviation law, statute of limitations, lex personalis, aviation agents, aircraft property rights, transportation contracts, torts, etc.). When the time is mature in the future, a single law on the application of private law of aviation can be formulated. See Wang, supra note 38, at 101-15.

54 Huachang Zeng, A probe into the legal countermeasures to solve the conflict of civil legal across the Taiwan Strait [解 决海峡两岸民事法律冲突的法律对策初探], 15(3) J. XIAMEN U. (Art \& Social Sciences) [厦门大学学报 (社会科学版)] 87 (1994). 
conflict of laws code. ${ }^{55}$ For the mainland, although there are no written interregional conflicts of laws rules, in long-term practice, conflict of laws issues will be resolved by the relevant conflict of laws rules in special laws. ${ }^{56}$

\section{Private Institutions Negotiation Model: The Supplementary, Feasible, and Optimal Option}

The conflict of laws issue in cross-strait direct flights could be resolved by the aforementioned uniform substantive law and conflict of laws models. Besides these two models, some scholars have proposed the model of an agreement signed by the Association for Relations across the Taiwan Straits and the Straits Exchange Foundation or air carriers operating direct flights. Agreements by unofficial private institutions would resolve the cross-strait conflict of laws issues by identifying substantive laws.

\section{Association for Relations across the Taiwan Straits and Straits Exchange Foundation Model}

Today, there are actual difficulties in enacting uniform substantive laws and interregional conflict of laws rules. Under the circumstances, it is worth considering legally binding, semi-official authoritative agreements signed by the Association for Relations across the Taiwan Straits and the Straits Exchange Foundation ${ }^{57}$ to clarify the rights and obligations of the parties and to resolve the cross-strait conflict of laws issues. On this method, some scholars have pointed out the cross-strait jurisdictional issue and maintained: "In the short term, it is the best resolution to sign an interregional agreement to manage the jurisdictional conflicts." ${ }^{, 58}$ Signing an agreement on cross-strait transportation, however, would be very complicated in practice and actually involve a complete analysis of all cross-strait air laws and regulations. The workload would be as good as formulating a uniform air law. An advisable approach is thus to reach separate agreements for separate issues and resolve frequent and obvious issues, such as the carrier liability. This seems feasible

55 People's Relations Regulations, arts. 41-63.

56 Xiaoyun Tian, Resolution of Interregional Conflict Law and China's Interregional Conflict of Laws [区际冲突法与我 国区际法律冲突的解决], 11(4) J. NoRTH CHINA U. TECH. [北方工业大学学报] 28 (1999).

57 Such an agreement is actually a legally binding interregional agreement, similar in nature to an international bilateral agreement, except that the subject of the signature is not State, but civil institutions in different jurisdictions in the same country. Each jurisdiction shall be implemented in accordance with the principle of bona fide.

58 Tao Li \& Zhangying Li, Conflict and Harmonization of Civil Jurisdiction Between the Mainland and Macao [浅析内地 与澳门民事管辖权的冲突与协调], 18(1), J. BeIJING U. AERONAUtiCAS \& Astronautics (Social Science Edition) [北京航 空航天大学学报 (社会科学版) 58 (2005). 
and operational. ${ }^{59}$

\section{Air Carrier Agreement Model}

If failing to adopt a full agreement between the Association for Relations across the Taiwan Straits and the Straits Exchange Foundation, would it be possible to negotiate an agreement between permitted air carriers operating the direct flights to unify the liability for passengers and consignors applying the same contractual conditions and liability rules?

Two models could serve as references for establishing this model: one is the 1995 IATA Intercarrier Agreement on Passenger Liability (hereinafter Kuala Lumpur Agreement; "IIA") IATA Intercarrier Agreement (hereinafter Miami Agreement; "MIA"). ${ }^{61}$ These two agreements involve carriers making voluntary promises to waive liability rules under the Warsaw Convention.

Although there are different rules on compensation and jurisdiction in the two sides' civil aviation laws, the related limitation is lower than the international convention standards or general level of international judicial practice. In addition, the aforementioned three traditional models have, to a certain extent, disadvantages. Therefore, if it is possible to build a model under the agreement of private institutions and consider the international characteristic-a uniform and modern trend on air transport liability and protection of passenger rights, it is worth considering a semiofficial agreement signed by China Air Transport Association on behalf of mainland carriers and Taiwan Airline Associations on behalf of Taiwanese carriers on the basis of friendly, equal, fair negotiation. At the same time, international air law conventions, international customs, and the IATA agreements could be used as references. $^{62}$ In this regard, carriers would be free to negotiate and adopt similar or the same general conditions in a transport contract and to regulate rights, obligations, and applicable laws in a cross-strait air transport legal conflict. This resolution is flexible, feasible, and free; it respects party discretion without official restraint. The

59 Wang, supra note 38, at 117.

60 Intercarrier Agreement on Passenger Liability, available at http://www.transportrecht.de/transportrecht_content/ 1145517809.pdf.

61 Agreement on Measures to Implement the IATA Intercarrier Agreement, available at http://www.transportrecht.de/ transportrecht_content/1268831842.pdf.

62 For example, Article 121 of Chapter 11(Supplementary Provisions) of the Civil Aviation Law of Taiwan, as revised in 2014, takes into account of the practice of international conventions. It provides: "If there is no stipulation in this Law and involves international matters, The Civil Aviation Administration may report to the Ministry of Communications for approval and application in accordance with the standards, recommendations, measures or procedures set forth in the relevant international conventions and their attachments." 
model is thus an optimal, but not perfect. In comparison with this model, in crossstrait aviation practice, since the cross-strait Spring Festival charter in 2003, any compensation and insurance issues have essentially adopted relevant practices in the Warsaw Convention and the Montreal Convention. This satisfies the need to promote economic and social development and to protect the two sides' real interests.

\section{Conclusion}

Cross-strait air transport has many legal conflicts in public and private law. These conflicts could be resolved by traditional uniform substantive law and interregional conflict of laws rules. Although uniform substantive law could permanently resolve the cross-strait air law conflict, it lacks real-life foundation. Formulating one interregional conflict of laws code would also pose challenges in practice. Making interregional conflict of laws patterns would separately be a last resort and help supposedly resolve legal conflicts. This approach, however, forbids remission and transmission. The mainland legislation forbids remission, ${ }^{63}$ while Taiwan's 'People's Relationship Regulation' allows it, ${ }^{64}$ which may engender new conflicts in interregional private law. Traditional approaches to the legal conflict of the crossstrait direct flights reveals that each model has its advantages and disadvantages. The cross-strait air law conflict cannot be completely resolved by a single method. Considering the specialty of cross-strait air transport and the status quo of air transportation, there could be a third path, beyond the traditional approaches, which would be a private agreement between the two sides' carriers or between the Association for Relations across the Taiwan Straits and the Straits Exchange Foundation to regulate rights and obligations, dispute resolution, and applicable laws. This would respect personal autonomy and parties' discretion to escape from any difficulties and barricades through official legislation to resolve any legal conflicts in the cross-strait direct flights.

Admittedly, the traditional uniform substantive law and conflict of laws models

63 PRC Law on Choice of Law for Foreign-related Civil Relationships [中华人民共和国涉外民事关系法律适用法] (passed on Oct. 28, 2010, enforced from Apr. 1, 2011), art. 9. It provides: "The foreign laws relating to foreign civil relationships do not include the conflict of laws rules of that country." As seen in Article 9, the situation of renvoi is excluded as the foreign laws do not include conflict of laws.

64 People's Relations Ordinance art. 43. It provides: "When applying the rules to the mainland China, if there are no corresponding rules in the mainland China or applying the Taiwanese laws according to the rules, then Taiwanese rules shall apply." Therefore, Taiwan acknowledges renvoi. 
are not incompatible but connected with inner logic. The conflict of laws model is an indirect model and must borrow substantive laws to resolve the conflict permanently. The newly-born private institution agreement has not reached its full level and effect. Considering the status quo of cross-strait relations, air legislation and each model's characteristics, it would be practical to combine and supplement each model to capitalize on the respective advantages of each model. The authors would advise to apply the private carrier agreement model at an early stage before proceeding to enact respective conflict of laws rules and uniform conflict of laws rules or substantive law if the legislation is mature or the two sides reunite to resolve the cross-strait air law conflict effectively.

Annex 1: Comparison of Liability in Cross-Strait Passenger Air Transportation

\begin{tabular}{|c|c|c|c|}
\hline \multirow{2}{*}{ Liability } & \multirow{2}{*}{$\begin{array}{c}\text { Taiwanese Region } \\
\text { (Not part of any Warsaw } \\
\text { System) }\end{array}$} & \multicolumn{2}{|c|}{ Mainland China } \\
\hline & & Domestic Laws & International Conventions \\
\hline $\begin{array}{l}\text { Legal } \\
\text { Sources }\end{array}$ & $\begin{array}{l}\text { 1. 'Civil Law'; } \\
\text { 2. 'Civil Aviation Law'; } \\
\text { 3. Act of Compensation for } \\
\text { Air Cargo; } \\
\text { 4. Measures for Dispute } \\
\text { Resolution for Civil Air } \\
\text { Transportation Passenger } \\
\text { and Air Carrier }\end{array}$ & $\begin{array}{l}\text { 1. General Principles of Civil } \\
\text { Law; } \\
\text { 2. Contracts Law; } \\
\text { 3. Torts Law; } \\
\text { 4. Civil Aviation Law; } \\
\text { 5. Regulations on Compensation } \\
\text { for Domestic Air Carrier }\end{array}$ & $\begin{array}{c}1999 \text { Montreal } \\
\text { Convention }\end{array}$ \\
\hline $\begin{array}{l}\text { Liability } \\
\text { Principles }\end{array}$ & $\begin{array}{l}\text { Non-Fault Liability (Art. } 654 \\
\text { of 'Civil Law'; Art. } 89 \text { and } \\
91 \text { of 'Civil Aviation Law') }\end{array}$ & $\begin{array}{l}\text { 1. Non-Fault Liability } \\
\text { (Contracts Law, Torts Law, } \\
\text { and General Principles of } \\
\text { Civil Law) } \\
\text { 2. Presumption of Negligence } \\
\text { (Civil Aviation Law) }\end{array}$ & $\begin{array}{l}\text { 1. Strict Liability: } \\
\leq 10,000 \text { SDR } \\
\text { 2. Presumption of } \\
\text { Negligence: }>10,000 \text { SDR }\end{array}$ \\
\hline $\begin{array}{l}\text { Liability } \\
\text { Subject }\end{array}$ & $\begin{array}{l}\text { 1. 'Civil Law': Air Carrier } \\
\text { 2. 'Civil Aviation Law': } \\
\text { Owner (Art. 89); Air Carrier, } \\
\text { Conditional Buyer, Lender } \\
\text { (Art. 90); Aircraft User or } \\
\text { Carrier (Art. 91); Air Crew, } \\
\text { Third Party (Art. 92) } \\
\text { 3. Air Cargo Compensation } \\
\text { Measures: Aircraft User or } \\
\text { Carrier }\end{array}$ & $\begin{array}{l}\text { 1. Air Carrier } \\
\text { (Contract Law Art. 302, } \\
\text { Civil Aviation Law Art. 124) } \\
\text { 2. Civil Aircraft Operator } \\
\text { (Torts Law Art. 71) } \\
\text { 3. High-Altitude Operators } \\
\text { (Torts Law Art. 73) }\end{array}$ & $\begin{array}{l}\text { Air Carrier (Art. 21), } \\
\text { Contractual Carrier, and } \\
\text { Actual Carrier (Art. 39) }\end{array}$ \\
\hline $\begin{array}{l}\text { Liability } \\
\text { Duration }\end{array}$ & $\begin{array}{l}\text { 'Civil Aviation Law': Death or } \\
\text { Injury due to Accidents During } \\
\text { Using Aircraft or Getting on or } \\
\text { off the Aircraft (Art. 91) }\end{array}$ & $\begin{array}{l}\text { Civil Aviation Law: During } \\
\text { Using Aircraft or Getting } \\
\text { on or off the Aircraft (Art. 124) }\end{array}$ & $\begin{array}{l}\text { During Using Aircraft or } \\
\text { Getting on or off the } \\
\text { Aircraft (Art. 21) }\end{array}$ \\
\hline
\end{tabular}




\begin{tabular}{|c|c|c|c|}
\hline $\begin{array}{c} \\
\text { Injury } \\
\text { and Death } \\
\text { Compensation } \\
\text { Scope and } \\
\text { Limit }\end{array}$ & $\begin{array}{l}\text { 1. Special Rule ('Civil Aviation } \\
\text { Law' Art. 93) } \\
\text { 2. 'Civil Law': Medical } \\
\text { Expenses, Extra Living Costs, } \\
\text { Funeral Costs (Art. 192); } \\
\text { Non-Property Damage } \\
\text { (Art. 194) Agreed Amount, } \\
\text { Lost Profits (Art. 216) } \\
\text { 3. 'Civil Aviation Law': } \\
\text { Standards Made by the } \\
\text { 'Ministry of Transportation' } \\
\text { and Approved by the } \\
\text { Executive Yuan (Art. 93) } \\
\text { 4. Measures for Compensation } \\
\text { for Air Cargos: Death: } \\
\text { 3 Million NTD; Severe Injury: } \\
\text { 1.5 Million NTD; Non-Death } \\
\text { or Severe Injury, Measured } \\
\text { by Actual Damage but No } \\
\text { More Than 1.5 Million NTD } \\
\text { (Art.3) }\end{array}$ & $\begin{array}{l}\text { 1. Special Rules (Civil Aviation } \\
\text { Law Art. } 129 \text { (2)) } \\
\text { 2. Medical Fees, Nursing Fees, } \\
\text { Transportation Fees, Lost } \\
\text { Income, Aid for Disability, } \\
\text { Compensation for Disability, } \\
\text { Funeral Fees, Death } \\
\text { Compensation, Mental Loss } \\
\text { Fees (Tort Art (s) } 16 \text { and 22) } \\
\text { 3. Civil Aviation Law: } \\
\text { International Passenger } \\
\text { Transportation 16600 SDR } \\
\text { (Art. 129) } \\
\text { 4. Domestic Passenger } \\
\text { Transportation Will Be 400,000 } \\
\text { RMB (Domestic Air Carrier } \\
\text { Compensation Limit Art. 3) }\end{array}$ & $\begin{array}{l}\text { Compensation Based } \\
\text { on Strict Liability: } \\
\text { Compensation } \leq 100,000 \\
\text { SDR }\end{array}$ \\
\hline $\begin{array}{l}\text { Limitless } \\
\text { Liability }\end{array}$ & $\begin{array}{l}\text { Injury due to Intentional or } \\
\text { Major Negligence } \\
\text { (Measures for Compensation } \\
\text { for Air Cargo Art. 6) }\end{array}$ & $\begin{array}{l}\text { 1. Intentional or Knowingly } \\
\text { Aware of the Damage but Act } \\
\text { Recklessly or Omission of Act } \\
\text { by Air Carrier and its Employer } \\
\text { or Agent (Civil Aviation Law } \\
\text { Art. 132) } \\
\text { 2. Agreed to Passenger on } \\
\text { Board but Did Not Issue the } \\
\text { Ticket (Civil Aviation Law } \\
\text { Art. 111) }\end{array}$ & $\begin{array}{l}>100,000 \text { SDR } \\
\text { Compensation }\end{array}$ \\
\hline $\begin{array}{l}\text { Reasons } \\
\text { for Waiver } \\
\text { of Liability }\end{array}$ & $\begin{array}{l}\text { 1. Force Majeure; } \\
\text { Passenger Negligence } \\
\text { ('Civil Law' Art. 654) } \\
\text { 2. Passenger Reasons or } \\
\text { Passenger Negligence } \\
\text { ('Civil Aviation Law' Art. 91) }\end{array}$ & $\begin{array}{l}\text { 1. Health Reasons for Passengers } \\
\text { (Civil Aviation Law Art. 124 } \\
\text { and Contracts Law Art. 302) } \\
\text { 2. Passenger Intentional or } \\
\text { Major Negligence } \\
\text { (Contracts Law Art. 302) }\end{array}$ & $\begin{array}{l}\text { Damage Is Not Done } \\
\text { by Air Carrier, or its } \\
\text { Hired Person, Agent's } \\
\text { Negligence, or Other } \\
\text { Inappropriate or Omission } \\
\text { of Act; or Damage Is Done } \\
\text { by Third-Party Negligence } \\
\text { or Other Inappropriate Act } \\
\text { or Omission of Act (Art. 21) }\end{array}$ \\
\hline $\begin{array}{l}\text { Liability } \\
\text { Insurance }\end{array}$ & $\begin{array}{l}\text { 1. Needs to Be Insured } \\
\text { ('Civil Aviation Law' } \\
\text { Art. 94, 95, and } 99 \text { (6)) } \\
\text { 2. Issued by the Standard No } \\
\text { Less than Compensation } \\
\text { (Measures for Compensation } \\
\text { for Air Cargo Damage Art. 5) }\end{array}$ & No Requirement & $\begin{array}{l}\text { Needs to Be Insured } \\
\text { Based on (Domestic Law) } \\
\text { (Art.50) }\end{array}$ \\
\hline $\begin{array}{l}\text { Statutes of } \\
\text { Limitation }\end{array}$ & $\begin{array}{l}\text { Two Years } \\
\text { ('Civil Law’ Art. 623) }\end{array}$ & $\begin{array}{l}\text { Three Years (General Principles } \\
\text { of Civil Law Art. 188) } \\
\text { Two Years (Civil Aviation Law } \\
\text { Art. 135) }\end{array}$ & Two Years (Art. 35) \\
\hline
\end{tabular}


